\title{
Portfolio Assessment to Enhance Students' Achievement in Learning Physical Education
}

\author{
Komarudin \\ Universitas Pendidikan Indonesia, Indonesia \\ komarudin_pko@upi.edu
}

\begin{abstract}
Students' achievement in learning physical education has always been measured using traditional assessment. The assessment, however is considered partial as it can only assess a few parts of the whole learning activity. It usually results in the outcome without considering the learning processes. Portfolio assessment appears to be an alternative to assess students' achievement as well as performance authentically especially in psychomotor domain. Using this type of assessment, teachers will be able to capture students' learning processes in its entirety. This is a quasi-experimental study with randomized pretestposttest control group design. The populations for this study was six classes of eighth graders and the samples were two classes selected using cluster random sampling. The data is collected by measuring students' learning achievement in psychomotor domains. Result of data analysis shows that, portfolio assessment is more effective than traditional assessment to enhance students' learning achievement in the psychomotor domains. Finally, this study suggests that portfolio assessment should be used in teaching and learning physical education since this type of assessment depict students' learning processes comprehensively.
\end{abstract}

Keywords: portfolio and traditional assessment, students' achievement, psychomotor domain, physical education

\section{INTRODUCTION}

To enhance the quality of teaching, there are several factors to fix such as the class management, the teachers' skills, and the evaluation. Evaluation is actually expected to blend in an integrated teaching and learning process. It is even to be the foundation of a good quality teaching and learning process. In relation to this, Komarudin (2012) states evaluation is not merely a collection of techniques, it is a process, a continuous process that underlies all good teaching and learning. Comprehensive integration among teaching, learning, and evaluation should actually be reflected through the process of teaching and learning. In the context of physical education, it is obvious that teachers play an important role in managing the process. For instance, teachers, within the process of teaching and learning, are able to make decisions either formally or informally aiming at making all the scenes in the teaching and learning change students' behaviors.

Teacher, especially in physical education learning, have been so far making a traditional assessment system which is not relevant to the process of teaching and learning. According to Melograno (2006) the dissatisfaction with traditional forms of assessment multiple choice tests, achievement tests, and standardized skill tests. These kinds of assessment make it nearly impossible to measure the broad range of skills and competencies. In addition, Wiggins (Mintah, 2003) traditional assessments measure common and narrowly defined knowledge that is incompatible with the aim of any robust education for lifelong learning. Therefore, the ongoing assessment nowadays can be considered less meaningful. In line with this, Sudana (2002) highlights that the assessment is not integrated yet in a process of teaching and learning. Cross-checking and giving adequate feedback to the students as assessment, whose purpose is to develop students' mastery, seem to be absent in the process of teaching and learning. What usually happens in reality is that teachers give assessment as a formality; their assessment does not come out as feedback that can be beneficial for the next processes.

In relation to traditional assessment, Melograno (2000) says that this type of assessment has several drawbacks. He explains these tests help measure a discrete skill or the recall of discrete information, but are limited when gathering evidence about the application of these abilities in "real-life" context. The so-called objective tests, which are a part of traditional assessment, are not contextual in collecting students' behaviors and are unable to describe their development comprehensively. This type of assessment has also narrow meaning in terms of educational perspective since teachers' decisions are final. This might be the reason why there are some criticisms to assessment based on test results. Sax (Zaenul, 2008) clarifies that among the shortcomings of implementing tests are: (1) tests invade students' rights; (2) tests causes anxiety and disturb the teaching and learning; (3) tests categorize students permanently; (4) tests actually 'punish' smart and creative students; (5) tests make discrimination; and (6) tests only measure limited learning outcome. Therefore, traditional assessment requires re-evaluation so that the quality of education, especially physical education, can be improved.

Assessment is supposed to have comprehensive measurement especially in psychomotor domains both in school and outside. In other words, it should be integrated with the teaching and learning to build active lifestyle which is actually the primary objective of physical education. To cope with that is not a piece of cake. Teachers will have to deal with the instability of young generation which has different values. Schulttze; Lutan state that the phenomenon of young generation culture development has shifted from survival society to excitement society. The symptom is a change in movement culture (Komarudin, 2012). To respond to this, upgrade and development of teaching experience is clearly required so that the educational objectives can be achieved. Meanwhile, physical education nowadays cannot raise the learning process since it emphasizes "teacher-centered learning" in 
which students do what their teachers ask them to. Teachers tend to use achievement approach in their teaching and learning so that their assignments are similar to sport training or exercise. The learning objective puts more focuses on skill mastery without any modification. Students then often feel frustrated since they think they fail to do the complex assignments given (Cholik \& Lutan, 1996).

A big challenge as the result of the decrease of the teaching and learning quality is the existence of motionless culture. Youths are too excited with browsing sport homepage or making global network. It is undeniable that this case can be beneficial for the development of knowledge about sport. However, computer and internet waste their time so that they are becoming motionless Wulf Preising (Lutan, 1999). This trend comes with negative impact even becomes a threat to health and life quality in general. Komarudin, (2012) describe the profile of young generation in a cynical way as follows; "now, in this generation, the youth are called the "O" generation. The "O" stands for "Obese". We now have the "obese generation" because of a high percentage of the population being obese due to lack of physical education and poor nutrition habits." Related to the trend, data reveal that children less participative in physical education will have health degradation such as obesity. Lundvall \& Meckbach (2008) states that the prevalence of obesity among children aged 6-11 more than doubled in the past 20 years, going from $6.5 \%$ in 1980 to $17.0 \%$ in 2006 . The rate among adolescents aged 12-19 more than tripled, increasing from $5.0 \%$ to $17.6 \%$.

Physical education in school needs to be a part of society's hope in solving social ills thus it can result the real human beings who are physically, spiritually, and socially healthy. In relation to the context of social life in America, the symptoms of non-healthy society are described by Kelly \& Melograno (2004), many people expect schools to solve our "social ills". We confronted with substance abuse, changes in family patterns, violence, terrorist-related threats, poor fitness among youth, childhood obesity, sexsually transmitted diseases, greater inequities between the "have" and "the have-nots," a TV and video game generation, high crime rates, poor schools performance, child abuse, teenage suicide, distruptive behavior, changing ethnic and linguistic diversity, and high dropout rates, to mention a few.

To cope with the aforementioned issued, portfolio is an alternative that is considered able to review any actual tendencies and critical issues in the society, including students. Students' experiences in the entire processes of teaching and learning are captured in a meaningful way to reach this purpose. An upgrade in physical education is the must, one of which is by implementing assessment appreciating students' experiences meaningfully. As the paradigm shifts in learning theories and children are threatened to be motionless, a radical change in physical education needs to be an occurrence. This change emphasizes integration among teaching, learning, and quality evaluation to gain quality standards in the curriculum realization. The change also refers to the new paradigm of learning compatible for physical education as follows.

One of the possible alternatives enabling to compile information to assess physical education comprehensively is portfolio assessment. According to the former researchers of portfolio such as Birgin \& Baki (2007) portfolio gives more reliable and dynamic data about students for teachers, parents, and also students themselves. Some of studies' results cited in Birgin \& Baki (2007), such as those of Costa \& Kallick (1995); Howard \& Le Mahieu (1995) reveal that portfolio is potential to allow learners (of all ages and kind) to show breadth and depth of their learning. Covington (1998) also says that student choice is key to ensuring high levels of motivation. In addition, Purkey and Novak (1984) very well say that when students make choices about their learning, motivation and achievement increase, when choice is absent, they decrease.

Lacy (2011), the portfolio facilitates teacher and student involvement and still maintains academic integrity by satisfying the need to be accountable. Student portfolio contain work completed, work in progress, goals, teacher feedback, self-evaluation commentary, reflection on activity and performance goals, and other achievements of students in each of the four learning domain. Therefore, those studies have proven that portfolio assessment gives comprehensive information and enhancement on motivation and responsibility of the students. In the context of physical education in Indonesia, there is little information on the influence of portfolio assessment to the improvement of physical education quality, especially those related to psychomotor domains of the students. Considering that, the question this study tries to answer is does portfolio assessment give significant influence to students' achievement in learning physical education especially in psychomotor domains?

\section{METHODS}

The method in this study is quasi-experiment with the randomized pretest-posttest control group design (Fraenkel \& Wallen, 2006). In the meantime, the population consists of six classes of eight graders in Bandung. From the population, some classes are chosen to be the sample through cluster random sampling (Ali, 2010). The samples are then classified into class A and class D. Furthermore, class A is chosen to be the experimental group which gets the treatment, in this case it is the portfolio assessment and class $\mathrm{D}$ is called the control group which gets the traditional assessment in physical education. To assess students' achievement, several instruments are administered as alternatives which have their own purposes as follows, to measure psychomotor domain is performance test in the form of rating scale and students' achievement test are used. Than to measure students' activities inside and outside the school, physical activity leisure questionnaire, and fitness workout schedule.

The use of several alternative instruments, according to Lo' pez \& Pastor (2013) is necessary to help students to improve their learning and teachers to 
improve their teaching. They further state that studies are needed to collaborate that the use of these instruments achieve these goals. Some of the instruments are not only used in pretest and posttest, they are also used in every learning process to see the development of student achievement. Nevertheless, instruments for students' activities are not given in any process of teaching and learning at all since they are for measuring outside school activities. Basically, the instruments used in the traditional evaluation are the same as those used in the portfolio one. What are not used in the traditional assessment are the outside school activity instrument and the daily behavior instrument. The data analysis technique employed in this study is t test (paired t test and independent t test) using SPSS for Windows 21 (Santoso, 2013).

\section{RESULT AND DISCUSSION}

The data collected are analyzed through statistical. The data themselves include students' achievement in psychomotor domain. The calculation covers means of pretest and posttest students' achievement in psychomotor domain is on Figure 1 below. Based on the calculation, it has been proven that portfolio assessment has higher differences in comparison with traditional assessment. The hypothesis is tested using paired t test and independent $\mathrm{t}$ test which aims at seeing influential differences between portfolio assessment and traditional assessment to enhance students' achievement in psychomotor domain. The calculation is on Table 1 below.

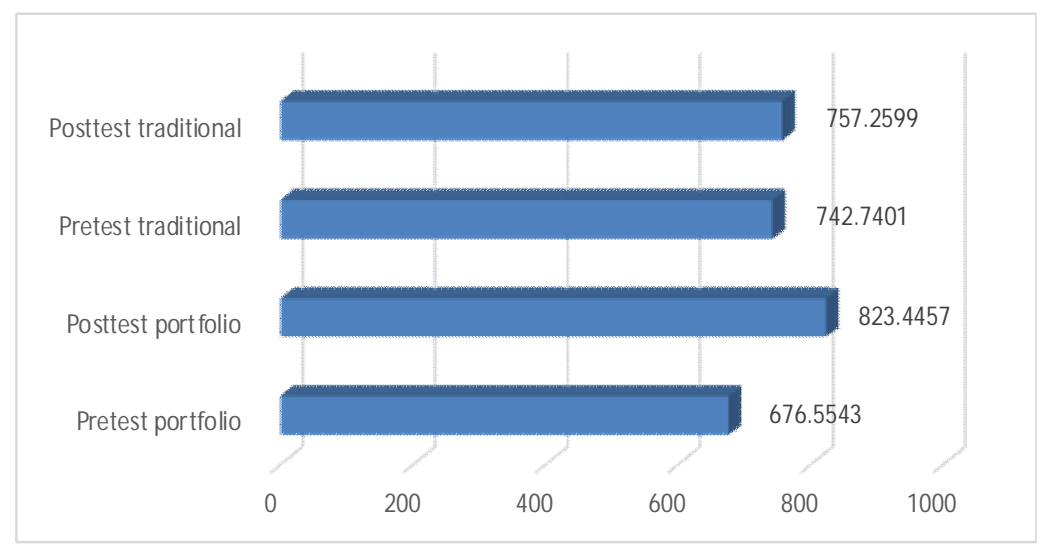

Figure 1

The Result of Pretest and Posttest's Students' Achievement

Table 1

The calculation of $t$ test (paired $t$ test)

\begin{tabular}{|c|c|c|c|c|c|c|c|c|}
\hline & \multicolumn{5}{|c|}{ Paired Differences } & \multirow{3}{*}{$\mathrm{t}$} & \multirow{3}{*}{ df } & \multirow{3}{*}{ Sig. (2-tailed) } \\
\hline & \multirow{2}{*}{ Mean } & \multirow{2}{*}{$\begin{array}{c}\text { Std. } \\
\text { Deviation }\end{array}$} & \multirow{2}{*}{$\begin{array}{l}\text { Std. Error } \\
\text { Mean }\end{array}$} & \multicolumn{2}{|c|}{$\begin{array}{l}95 \% \text { Confidence Interval of } \\
\text { the Difference }\end{array}$} & & & \\
\hline & & & & Lower & Upper & & & \\
\hline $\begin{array}{l}\text { Pretest portfolio Posttest } \\
\text { portfolio }\end{array}$ & -55.817424 & 40.133785 & 5.917404 & -67.735687 & -43.899161 & -9.433 & 45 & .000 \\
\hline $\begin{array}{l}\text { Pretest tradisional Posttest } \\
\text { traditional }\end{array}$ & -14.519879 & 40.516545 & 5.973839 & -26.551807 & -2.487950 & -2.431 & 45 & .019 \\
\hline
\end{tabular}

Table 2

The results of Independent samples test

\begin{tabular}{|c|c|c|c|c|c|c|c|c|c|c|}
\hline \multicolumn{11}{|c|}{ Independent Samples Test } \\
\hline & & \multicolumn{2}{|c|}{$\begin{array}{c}\text { Levene's Test } \\
\text { for Equality of } \\
\text { Variances } \\
\end{array}$} & \multicolumn{7}{|c|}{ t-test for Equality of Means } \\
\hline & & \multirow[t]{2}{*}{$\mathrm{F}$} & \multirow[t]{2}{*}{ Sig. } & \multirow[t]{2}{*}{$\mathrm{t}$} & \multirow[t]{2}{*}{$\mathrm{df}$} & \multirow[t]{2}{*}{$\begin{array}{l}\text { Sig. (2- } \\
\text { tailed) }\end{array}$} & \multirow[t]{2}{*}{$\begin{array}{c}\text { Mean } \\
\text { Difference }\end{array}$} & \multirow[t]{2}{*}{$\begin{array}{c}\text { Std. Error } \\
\text { Differenc } \\
\text { e }\end{array}$} & \multicolumn{2}{|c|}{$\begin{array}{l}\text { 95\% Confidence } \\
\text { Interval of the } \\
\text { Difference }\end{array}$} \\
\hline & & & & & & & & & Lower & Upper \\
\hline \multirow{2}{*}{$\begin{array}{l}\text { Learning } \\
\text { Achievement }\end{array}$} & $\begin{array}{l}\text { Equal variances } \\
\text { assumed }\end{array}$ & .242 & .624 & 8.365 & 90 & .000 & 70.33730 & 8.40847 & 53.63240 & 87.04220 \\
\hline & $\begin{array}{l}\text { Equal variances } \\
\text { not assumed }\end{array}$ & & & 8.365 & 89.992 & .000 & 70.33730 & 8.40847 & 53.63238 & 87.04222 \\
\hline
\end{tabular}

Based on the calculation result in Table 1, it is known that the value of the portfolio assessment 0.000 and the traditional assessment $0.19<0.05$, thus Ho is rejected, meaning that there is a significant effect of portfolio and traditional assessment to enhance learning achievement especially in psychomotor domain. Furthermore, to know the effect difference between the two assessments need to do independent samples test. The calculation results can be seen in Table 2.

Furthermore, the development of student learning achievement in portfolio assessment in each subject matter, looks like in Figure 2. Based on the results of independent samples test was obtained value 
$0.000<0.05$, thus means Ho rejected, meaning there is a significant difference in the influence of portfolio and traditional assessment to learning achievement in psychomotor domain in learning physical education. Judging from the difference in scores from both assessments, the assessment of the portfolio had a
146.891 greater than 14.519 traditional assessment score. Thus, it can be concluded that the portfolio assessment is better than the traditional assessment to learning achievement in psychomotor domain in learning physical education.

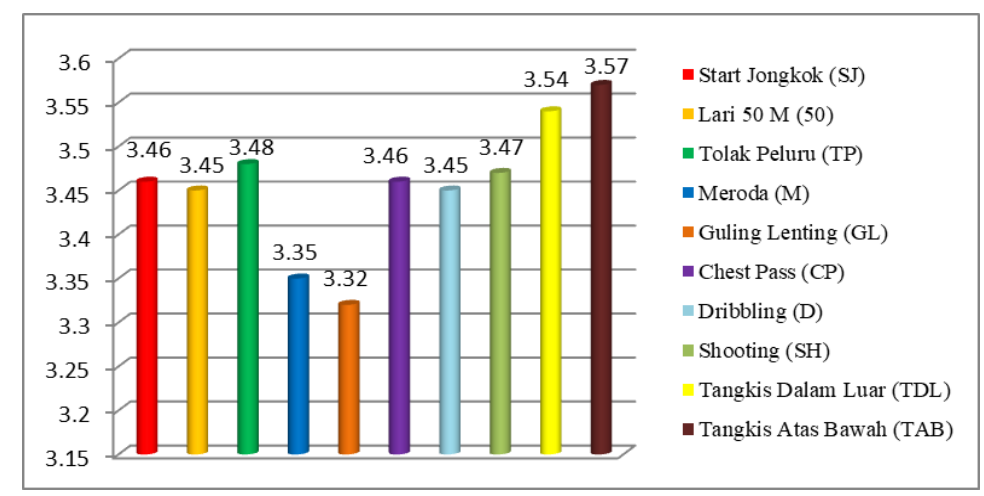

Figure 2

The average score of psychomotor domain in each subject matter

Portfolio assessment is more effective than traditional assessment to enhance student achievement in learning physical education especially in psychomotor domain. According to Cole, Ryan, \& Kick (1995) that portfolio assessment has become widely used in educational settings as a way to examine and measure progress, by documenting the process of learning or change as it occurs. Portfolios extend beyond test scores to include substantive descriptions or examples of what the student is doing and experiencing. Fundamental to authentic assessment or performance assessment in educational theory is the principle that children and adolescents should demonstrate, rather than tell about, what they know and can do.

Shaklee, Barbour, Ambrose, \& Hansford (1997) argue that, documenting progress toward higher order goals such as application of skills and synthesis of experience requires obtaining information beyond what can be provided by standardized or norm-based tests. In "authentic assessment", information or data is collected from various sources, through multiple methods, and over multiple points in time (Contents of portfolios, sometimes called artifacts or evidence) can include drawings, photos, video or audio tapes, writing or other work samples, computer disks, and copies of standardized or program-specific tests. Data sources can include parents, staff, and other community members who know the participants or program, as well as the self-reflections of participants themselves.

The other, NASPE (2004) said that, portfolio can provide a comprehensive view of student learning and achievement that is performance based and authentic. Potentially, portfolio tasks demonstrate the application of skills and knowledge that students are expected to achieve to become a physically educated person. Whereas, Dez, Moon \& Meyer (1992) argue that performance is assesses in a context more like that encountered in real life. In portfolio assessment, students have an opportunity to analyze their skills and their friends' skill when in group work. Related to this issue, Kirk; O'Sullivan \& Fortrman (1997) think that the ability to analyzed skills performed by peers and self in class, the students project might be to analyze a particular skill or skills, identify the critical performance elements and cues, determine practice strategies, and ultimately perform the skill. NASPE (O'Sullivan \& Fortman, 2097) also add that if students are able to make their own decisions regarding the products they complete and include in the portfolio, which demonstrate their achievement of outcomes, then the portfolio encourages individualized and developmentally appropriate learning. In physical education, teachers need to really pay attention to the students' readiness regarding what they are going to learn since Landers (Lutan, 1999) agree that readiness to do a particular movement/motion in physical education is a key factor to the good quality outcomes. Students then need to dig their skills and improve motivation so that their interest and talent meet effectively.

\section{CONCLUSION}

Based on data analysis supported by several theoretical frameworks, it can be concluded that portfolio assessment is more effective than traditional assessment to enhance students' achievement especially in psychomotor domain in learning physical education.

\section{REFERENCES}

[1] Ali, M. 2010. Metodologi dan Aplikasi Riset Pendidikan. Bandung: Pustaka Cendekia Utama.

[2] Birgin \& Baki. 2007. The Use of Portfolio to Assess Student's Performance. Journal of Turkish Science Education, 4(2).

[3] Cholik, M., \& Lutan, R. 1996. Pendidikan Jasmani dan Kesehatan. Jakarta: Ministry of Education and Culture.

[4] Cole, D. J., Ryan, C. W., \& Kick, F. 1995. Portfolios Across The Curriculum and Beyond. Thousand Oaks, CA: Corwin Press. 
[5] Dez, M., Moon, J., \& Meyer, C. 1992. What do We Want Students to Know? And other Important Questions. Educational Leadership, 49(8), 38-42.

[6] Fraenkel, J. R., \& Wallen, N. 1993. How to Design and Evaluate Research in Education. New York: McGrawHill Inc.

[7] Kelly \& Melograno. 2004. Developing the Physical Education Curriculum: An Achievement Based Approach. New York: Human Kinetics.

[8] Kirk, D. O'Sullivan, M. \& Fortman. 1997. Using Portfolio to Enhance Student Learning and Assessment. Journal of Physical Education, 68, 7-16.

[9] Komarudin. 2012. Penerapan Model Evaluasi Portofolio dan Model Evaluasi Tradisional terhadap Hasil Belajar Domain Kognitif, dan Domain Afektif Siswa SMP YAS Kota Bandung. Jurnal Pendidikan Jasmani dan Olahraga, 7(1), 27-32.

[10] Lacy, Alan, C. 2011. Measurement \& Evaluation in Physical Education and Exercise Science. San Fransisco: Pearson Education, Inc.

[11] Lo'pez-Pastor, et al. 2013. Alternative Assessment in PhysicalEducation: a Review of International Literature. Sport Education and Society, 18: 57-76.

[12] Lundvall, S \& Meckbach, J. 2008. Mind the Gap: Physical Education and Health and The Frame Factor Theory as a Tool for Analyzing Educational Settings. Physical Education \& Sport Pedagogy, 13, 345-364.

[13] Lutan, R. 1999. Azas-azas Pendidikan Jasmani Pendekatan Pendidikan Gerak di Sekolah Dasar. Bandung: FPOK UPI.

[14] Melograno, V. J. 2000. Designing a Portfolio System for K-12 Physical Education: A Step-by-Step Process. Journal Measurement in Physical Education and Exercise Science, 4(2), 97-115.

[15] Melograno, V. J. 2006. Professional and Student Portfolios for Physical Education. New York: Human Kinetics.

[16] Mintah, J. K. 2003. Authentic Assessment in Physical Education: Prevalence of Use and Perceived Impact on Students' Self-Concept, Motivation, and Skill Achievement. Journal Measurement in Physical Education and Exercise Science, 7(3), 161-174.

[17] National Association for Sport and Physical Education (NASPE). 2000. Moving into the Future. National Standards Physical Education. New York: NASPE.

[18] Santoso, S. 2013. Menguasai SPSS 21 di Era Informasi. Jakarta: PT Elex Media Komputindo.

[19] Shaklee, B. D., \& Viechnicki, K. J. 1997. A Qualitative Approach to Portfolios: The Early Assessment for Exceptional Potential Model. Journal for the Education of the Gifted, 18(2), 156-170.

[20] Sudana, N. 2002. Kurikulum Berbasis Kompetensi untuk Sekolah Menengah Kejuruan (SMK) Mata Pelajaran Pendidikan Jasmani. Jakarta: Ministry of National Education.

[21] Zaenul, A. 2008. Locus of Control, Self Esteem, dan Tes Baku. Journal of Historical Studies, 1(2), 1-12. 